\title{
Inherent Problems in the Use of Pretrial Hypnosis on a Prospective Witness
}

\author{
Bernard L. Diamond $\dagger$
}

Recently, hypnotism of witnesses and victims for purposes of memory enhancement and mvestigation has become widespread in law enforcement. ${ }^{1}$ One source ${ }^{2}$ reports that recent recipients of special training in the induction of hypnosis include:

(1) police personnel in Los Angeles, Portland, Seattle, Denver, Houston, San Antonio, Washington, D.C., and New York;

(2) FBI officers;

(3) the Air Force Special Investigations Unit; and

(4) the Alcohol, Tobacco and Firearms Bureau of the Treasury Departinent.

Even in small communities police officers and sheriffs have received such training, while in others cooperative psychiatrists and psychologists have been retained for hypnotic investigations.

Unfortunately, sensitivity to the limitations and hazards of hypnotism and especially to the myriad ways of intentionally and unintentionally suggesting responses to the subject requires much more experience and training. ${ }^{3}$ In my opinion, even psychiatric and psycho-

$\dagger$ Professor of Law, University of California, Berkeley; Clinical Professor of Psychiatry, University of California, San Francisco. A.B. 1935, University of California, Berkeley; M.D. 1939, University of California, San Francisco.

This Article, in part, was presented as the Distinguished Lecture for the American Academy of Psychiatry and Law on May 13, 1979 in Chicago. Acknowledgment is made to all of the defense attorneys in the cases in which I participated for their indispensable help. I am particularly indebted to Thomas S. Worthington, Esq., of Salinas, California, for the wealth of case law material and àrguinents he provided ine.

1. Monrose, Justice With Glazed Eyes: The Growing Use of Hypnotism in Law Enforcement, JURIS Doctor, Oct./Nov. 1978, at 54.

2. Id. at 55 .

3. The recent popularity of hypnosis among law enforcement personnel inay be attributable in large part to three books, H. Arons, Hypnosis in Criminal Investigation (1967); W. BRYAN, Legal Aspects of HypNosis (1962); M. Teitelbaum, HypNosis Induction Technics (1969). These books make extravagant claims of the usefuhress and reliability of hypnosis for criminal investigative purposes. Bryan, for example, states on the basis of personal experience that

it is extremely difficult for a subject to lie while in a deep hypnotic trance. What happens is this: The questions are directed at the subconscious mind rather than the conscious mind, and hence the true answers come from the subconscious inind. This is especially true if the questions are rapidly fired one after the other. The patient does not have time 
logical professionals highly skilled in the use of hypnosis for therapeutic purposes are apt to be naive in recognizing its limitations as a "truth-telling" technique.

Absent judicial intervention, however, the hypnosis "boom" seems likely to continue. The technique of hypnosis induction is easily learned. A police officer can becoine a reasonably skilled hypnotist in a few lours of practice, with or witlout fornal instruction. Thus it becomes critical to reexamine the general rule of law that hypnotically induced testimony is admissible, but that its credibility may be attacked.

In many cases, presentation to the jury of all facts, wliether legally relevant or not, inay be desirable. ${ }^{4}$ Indeed, I have often expressed the opimion that traditional rules of evidence restricting the information available to the trier of fact inay impede a just decision. ${ }^{5}$ This principle does not, lowever, apply to the testimony of witnesses whose inemories have been previously enhanced by hypnosis. I believe that once a potential witness has been lypnotized for the purpose of enhancing memory his recollections have been so contaminated that he is rendered effectively incoinpetent to testify. Hypnotized persons, being extremely suggestible, graft onto their ineinories fantasies or suggestions deliberately or unwittingly commumicated by the liypnotist. After hypnosis the subject cannot differentiate betwcen a true recollection and a fantasy or a suggested detail. Neither can any expert or the trier of fact. This risk is so great, in iny view, that the use of hypnosis by police on a potential witness is tantamount to the destruction or fabrication of evidence. Recently, some courts have shown a healthy suspicion of the veracity of this sort of testimony. ${ }^{6}$ Yet even under stringent safeguards, including presentation to the trier of fact of the fullest possible infor-

to "think" on a conscious level; and because his thinking process is distributed by hypnosis, he can only release information from the subconscious mind. He therefore invaria-

bly responds with the correct answer. These conchusions have been verified by

Polygraph and Truth Serum examinations.

W. BRYAN, supra, at 245.

The incautious approach of Arons is demonstrated in his belief that "instruction by physicians would [not] be advantageous." H. ARONS, supra, at 29. Arons similarly understates the inportance of divulging the use of hypnosis to the tricr of fact, viewing this as "not really pertinent to the matter." Id. at 27. For an example of Teitelbaum's approach, see note 7 infra.

Another author of articles and books aimed at law enforcement personnel who strongly advocates the use of hypnotism in criminal investigation is Dr. Martim Reiser. Dr. Reiser claims that his use of hypnosis in criminal investigation has resulted in "an approximate 60 percent increment of success over traditional interrogation techniques." Reiser, Hypnosis as a Tool in Criminal Investigation, The Police Chief, Nov. 1976, at 36.

4. Dieden \& Gasparich, Psychiatric Evidence and Full Disclosure in the Criminal Trial, 52 Calif. L. Rev. 543 (1964).

5. See, e.g., Diamond \& Louisell, The Psychiatrist as an Expert Witness: Some Ruminations and Speculations, 63 MiCH. L. REv. 1335, 1350-54 (1965).

6. The United States Court of Appeals for the Nimth Circuit, for example, has urged proce- 
mation on the effects of hypnosis, the trier will not be able to sort out reality from witness fantasy and weigh this testimony properly.

It appears that the principal reason for the continuing admission of hypnotically enhanced testimony is an inadequate understanding of the nature of hypnosis and its impact on the process of recall. In most cases, busy judges have simply lacked the benefit of counsel who cogently presented the nature of hypnosis, of scholarly authority that apphed scientific research to legal questions, and of expert testimony which dispassionately assessed the high risks of evidentiary distortion or abuse. Once, however, a court has this evidence of the nature of hypnosis before it, I believe that it need not and will not follow precedents decided by courts that had to reach a decision without a clear idea of the inherent danger to the factfinding process posed by the use of hypnosis on witnesses.

This Article first reviews the nature and history of hypnosis. It then discusses the reported cases and surveys the sparse legal literature on the subject. Thereafter, the Article argues that testimony by previously hypnotized witnesses should never be admitted into evidence.

dural safeguards for the use of such testimony. United States v. Adams, 581 F.2d 193 (9th Cir.), cert. denied, 439 U.S. 1006 (1978).

7. The following legal issues concerning the use of hypnosis will not be discussed except insofar as they relate to this topic:

(a) Use of hypnosis as a coercive or suggestive instrument by one person to cause another to commit a criminal act with consequent relevance to the defense of the hypnotized person charged with the crime and to the prosecution of the hypnotist, See, e.g., P. Reiter, AnTisocial OR Criminal Acts and Hypnosis: A Case Study (1958). See also Erickson, An Experimental Investigation of the Possible Anti-Social Use of Hypnosis, 2 Psychiatry 391 (1939).

(b) Use of hypnosis by law enforcement agents, with or without the consent of the subject, for the obtaining of a confession. This use was vigorously condemned in Leyra v. Denno, 347 U.S. 556 (1954). For details of the inproper hypnotisin used upon Leyra, see also Levy, Hypnosis and Legal Immutability, 46 J. CRIM. L.C. \& P.S. 333, 342 n.61 (1955). Despite this unequivocal prohibition of such use by the United States Supreme Court, the suspicion remains that this prac-. tice contimues. A "how to" book on hypnosis written by a lawyer-hypnotist and directed at law enforcement personnel gives fully detailed instruetions on what to say and how to behave in order to hypnotize a defendant without his being aware that this is happening. The author prefaces his description by stating: "Without going into the ethics of its use, we will merely present here a technic [sic] for involuntarily hypnotizing a criminal suspect." M. Teitelbaum, HyPNosis INDUCTION TECHNICS 168 (1969).

(c) Defense use of hypnosis on a defendant for the purpose of establishing his imnocence or at least eliciting some information helpful to the defense. In People v. Sirhan, 7 Cal. 3d 710, 497 P.2d 1121, 102 Cal. Rptr. 385 (1972), for example, I hypnotized the defendant in order to obtain information which imight underpin a dininished capacity defense.

(d) Use of hypnosis by a psychiatric or psychological expert as part of a clinical examination that is to serve as the basis of an expert opimion. Such use has occurred both with and without the consent of the subject and has been einployed by experts for the defense, experts for the prosecution (or police), and by court-appointed experts. Although there is still some controversy in other American jurisdietions, it is settled in California that information obtained through the use of hypnosis is admissible as part of the foundation for an expert's opinion of a defendant's 


\section{The NATURE AND History of HypNosis}

There are many descriptions of hypnosis. Webster's Dictionary defines it as "[a] state that resembles sleep but is induced by a hypnotizer whose suggestions are readily accepted by the subject." 8 Perhaps the best description is found in the characteristics observed by Hilgard in subjects highly susceptible to hypnosis:

1. Subsidence of the planning function. The hypnotized subject loses initiative and lacks the desire to make and carry out plans of his own ....

2. Redistribution of attention .... [U]nder hypnosis selective attention and selective inattention go beyond the usual range . . . . 3. Availability of visual memories from the past, and heightened ability for fantasy-production . . . . The memories are not all veridical, and the hypnotist can in fact suggest the reality of memories for events that did not happen.

4. Reduction in reality testing and a tolerance for persistent reality distortion ... . Reality distortions of all kinds, including acceptance of falsified memories . . . and all manner of other unrealistic distortions can be accepted without criticism within the hypnotic state.

5. Increased suggestibility. The suggestibility theory of hypnosis is so widely accepted that hypnosis and suggestibility come to be equated by some writers on hypnosis.

6. Role behavior. The suggestions that a subject in hypnosis will accept are not limited to specific acts or perceptions; he will, indeed, adopt a suggested role and carry on complex activities corresponding to that role.

7. Amnesia for what transpired within the hypnotic state . . . [Amnesia] is not an essential aspect of hypnosis. . . . Yet it is a very common phenomenon, and it can be furthered through suggestion.?

These empirical facts about the hypnotic state are generally ac-

mental state. People v. Cornell, 52 Cal. 2d 99, 338 P.2d 447 (1959), is authority for such use by the defense expert when the subject consents.

(e) Use of hypnosis to calm a nervous or distraught witness so that his credibihity may be enhanced. See W. BRYAN, supra note 3, at 194: "An important legitimate use of hypnosis exists with the purpose in inind of relaxing this nervous witness and creating an aura of calm self confidence so that she may present her evidence in a manner which the truthfuhiess of the evidence has every right to demand."

(f) Its use for the purpose of enhancing the memory of a witness to facilitate the investigation of a crime or tort. A recent example is the sensational Chowehilla kidnapping case where the bus driver was able to recall a key license plate number. See Monrose, supra note 1. For an example of its investigatory use in a tort action, see Wyller v. Fairchild Hiller Corp., 503 F.2d 506 (9th Cir. 1974), as modified with respect to the crucial issue of admissibility of hypnotically adduced testimony by United States v. Awkard, 597 F.2d 667, 670 (9th Cir. 1979).

8. Webster's New Collegiate Dictionary 563 (1976).

9. E. Hilgard, THE EXPERIENCE OF HyPNOSIS 6-10 (1968). 
cepted as verifiable scientific observations. ${ }^{10}$ However, there is much less agreement on the theories proposed to explain these facts. Barber and Calverley have explamed hypnosis in behavioristic and situational terms; ${ }^{11}$ Hilgard has described it as a particular estabhshed state; ${ }^{12}$ Sarbin and Andersen, in terms of role enactment; ${ }^{13}$ and Pavlov, as a partial sleep state. ${ }^{14}$

The existence of various conflicting theories that attempt to ex- $\checkmark$ plain the phenoinenon of hypnosis does not inean that hypnotism is unscientific. ${ }^{15}$ As medical treatment it is indeed legitimate and scientific. This fact, however, has no relevancy whatsoever to its use in a legal context or to the question of the admissibility of testimony of witnesses who have had their recall manipulated by hypnosis. Unfortunately, this kind of uncritical leap, as well as reliance on unscientific claims, has typified legal treatment of hypnosis. ${ }^{16}$

The history of hypnosis undoubtedly begins in ancient times with artifically induced somnambulism, and something like it is practiced in many primitive societies. ${ }^{17}$ However, accurate information differentiat-

10. Hilgard, Evidence for a Developmental-Interactive Theory of Hypnotic Susceptibility, in Hypnosis: Research Developments and Perspectives 387 (E. Fromm \& R. Shor eds. 1972) [hereinafter cited as RESEARCH].

11. Barber \& Calverley, The Relative Effectiveness of Task-Motivating Instructions and Trance-Induction Procedure in the Production of "Hypnotic-Like" Behaviors, 137 J. NeRvous \& Mental Disease 107 (1963).

12. Hilgard, Altered States of Awareness, 149 J. Nervous \& Mental Disease 68 (1969).

13. Sarbin \& Andersen, Role-Theoretical Analysis of Hypnotic Behavior, in HANDBOOK OF Clinical and Experimental Hypnosis 319 (J. Gordon ed. 1967).

14. Pawlow, The Identity of Inhibition with Sleep and Hypnosis, 17 ScIENTIFIC MONTHLY 603 (1923).

15. But it does mean that the law's quest for certainty is unscientific as well as futile. See generally Diamond, The Scientific Method and the Law, 19 HASTiNGs L.J. 179 (1967).

16. Compare W. BRYAN, supra note 3, at 245: "It has been my personal experience that it is extremely difficult for a subject to lie while in a deep hypnotic trance," with Redhch, Ravitz, \& Dession, Narcoanalysis and Truth, 107 AM. J. PsYcH. 586 (1951). See also Herman, The Use of Hypno-Induced Statements in Criminal Cases, 25 OHo STATE L.J. 1 (1964), naively relying on the equivocal testimony of the expert witness in the unreported case of State v. Nebb, No. 39540 (Ohio C.P., Franklin County, May 28, 1962), that there was no "probability" (though there was a "possibility") of a subject's lying under lyypnosis. The Nebb case is described in Teitelbaum, Admissibility of Hypnotically Adduced Evidence and the Arthur Nebb Case, 8 ST. Louis L.J. 205 (1963). Compare Sheehan, Hypnosis and the Manifestations of "Imagination", in HyPNOSIs: RESEARCh Developments AND Perspectives 293 (E. Fromm \& R. Shor eds. 1972) (reviewing research on fantasy production, role-playing, imagination, hallucinations, etc. in the hypnotic state) with the following statement from 9 ENCYCLOPAEDIA BrTTANNICA, MACROPAEDIA 139 (1979):

Hypnosis has not been found reliable in obtaining truth from a reluctant witness. Even if it were possible to induce hypnosis against one's will, it is well documented that the hypnotized individual still can willfully he. It is of even greater concern that cooperative hypnotized subjects remember distorted versions of actual events and are themselves deceived. When recalled in hypnosis, such false memories are accompanied by strong subjective conviction and outward signs of conviction that are most compelling to almost any observer. Caution and independent verification are essential in such circumstances.

17. In ancient and primitive societies trance states frequently were induced through drugs 
ing artificially induced somnambulism from spontaneous and psychotic trance states is not available for the period before the late eighteenth century. That was the era of Franz Anton Mesmer's "animal magnetism" and of the artificial somnambulisin (later known as "hypnotism") ${ }^{18}$ of his disciple, the Marquis de Puységur. Froin then to the present time controversy has surrounded hypnosis. It has passed through three or four cycles in which intense interest was followed by condemnation as quackery or by discovery of a better substitute for a specific use. Hypnosis thus periodically fell into disrepute and became the province of nonnadic faith healers, spiritualists, and a wide variety of quacks. ${ }^{19}$ Late eighteenth-century interest in hypnosis waned when a French Royal Commission denounced Mesmer as a charlatan. ${ }^{20}$ In the mid-mineteenth century the discovery of ether anesthesia displaced interest in psychological anesthesia by hypnosis. ${ }^{21}$ Then in the late

and toxic chemicals and may have been more analogous to the moderu "truth serums" than to hypnosis. Rogers, Egyptian Psychotherapy, 9 CiBa Symposia 617, 621 (1947).

18. Modern interest and research in hypnosis date from 1778 when Mesmer, a Viennese physician, inoved to Paris and established his clinic for the practice of "animal magnetism." F.A. Mesmer, Mémoire sur la DÉcouverte du Magnétisme Animal (Geneva 1779). Mesmer's magnetic treatinents, however, ordinarily did not include the induction of sleep or trance states and, strictly speaking, "inesinerism," "animal inagnetism," and "hypnotism" are not synonymous, although they are often incorrectly used thus. The first two terms apply to the treatment of illness by the touching of the patient and the supposed transmission of inagnetic influences from the therapist's body to the patient's. Mesiner's disciple, the Marquis de Puységur, treated a young peasant for toothache by the usual animal magnetic "passes." To de Puységur's surprise, his patient fell into a trance state in which he appeared to be asleep but was able to talk and answer questions. This is the first fully documented case of the induction of artificial somnambulism. Marquis de Puysegur, Memoires Pour Servir a L'Histoire et A L'Établissement du MAGNÉtisme ANIMAL 28-33, 390 n.131 (London 1786).

19. J. Bramwell, Hypnotism, Its History, Practice and Theory passim (2d ed. 1906).

20. Composed of famous scientists and headed up by Benjamin Franklin, in 1784 it investigated Mesmer and the practice of animal magnetisin and denounced both. It attributed the benefits of his inagnetic treatments to his patients' "imagimation." RAPPORT DES COMMISSAIRES Charges par le Rol, de l'Examen du Magnétisme Animal 64 (Paris 1784). Mesmer fled Paris and animal magnetism, and induced somnambuhism fell into disrepute.

21. A revival of inedical and scientific interest in hypnosis occurred in 1837 in England. In that year, Dr. John Elliotson began treating patients in a London hospital with inesmeric methods and his demoustrations of the efficacy of the treatments aroused great public and professional interest. Rosen, From Mesmerism to Hypnotism, 9 CibA Symposia 838, 841 (1948). Dr. James Esdaile returned to England from a long practice of medicine and surgery in lndia and informed Elliotson of his observation there of the use of artificially induced trance states as an anesthetic in inajor surgical operations. In 1843, after experiments in London, Elliotson published numerous case reports of successfuI surgical operations performed painlessly on patients in a trance state. $J$. Elliotson, Numerous Cases of Surgical Operations Without Pain in the Mesmeric STATE (London 1843). In the saine year, Jaines Braid published in London a famous work in which he coined the word "hypnosis" to designate the artificially induccd somnambulistic state. J. Braid, Neurhypnology, or the Rationale of Nervous Sleep (London 1843). A medical journal also appeared to pubhsh the inany medical reports and investigations being done in the field. The Zoist: A Journal of Cerebral Physiology \& Mesmerism, and their ApplicaTIONS TO HUMAN WELFARE (published in London froin March 1843 to January 1856). Most of the reports emphasized the anesthetic properties of hypnosis, but the therapeutic aspects remained 
nineteenth century ${ }^{22}$ its use in the treatment of nervous and mental disease $^{23}$ gave way to the psychoanalytic movement led by Sigmund Freud's new theories ${ }^{24}$ of causation and treatment of nervous and eino-

of much interest. Efforts were made to dissociate medical and surgical use of hypnosis from its earlier mystic, supernatural, and quack images. The reports in The Zoist were written in arr objective, scientific manner. Many were by dentists reporting painless tooth extractions through the use of hypnosis.

Notwithstanding this activity, two factors produced a sharp decline of interest in and inedical respectability of the mesmeric movement. First, in 1846 painless surgery through the patient's inhalation of ether was discovered. W.T.G. MORTON, REMARKS ON THE PROPER MODE OF ADMINISTERING SULPHURIC ETHER BY INHALATION (Boston 1847). Immediately, chemical anesthesia-ether or chloroform-proved successful throughout the world. Second, the English medical hypnotists were fascinated by phrenology. Phrenology began as a genuine scientific study of the morphology of the brain, F. GALI \& J. SpURzheim, ANATOMIE ET Physiologie du SySTeme Nerveux en Genéral, et du Cerveau en Particulier (1810-1819), but enthusiastic followers soon transformed it into a pseudo-science. By the mid-nineteenth century, it was in disrepute in England and all reputable medical and scientific interest in hypnosis had ceased as well. Rosen, supra, at $843-44$.

22. Hypnosis as a therapeutic method was soon revived, this time in France. A.A. Liébeault had read inany of the English writings on hypnosis, and he experimented with its use on many of his patients at his clinic in Nancy. He described his successful treatment of a wide variety of nervous and medical conditions in his 1866 book, A. Liébeault, Le Sommeil ProvoquE et Les ÉTATS ANALOGUES. This book is of great significance in psychotherapy as the first to show an awareness that the treatment techniques were purely psychological and that their effects were not due to magic, religious miracles, or inysterious natural forces such as magnetism. See also Diamond, Ten Great Books in the History of Psychiatry, 12 Mental Hospitals 32 (1961). Liebeault was not given appropriate recognition for his pioneer book, for the first edition (1866) of his book sold only two copies and reınained almost entirely unknown until a new edition was published in 1889. The new edition was much abridged and its title page gave no indication that there had been an earlier edition. By 1889 , the concept of psychotherapy as a psychological method of treatunent was no longer a novelty.

23. Hypnosis had rapidly become an accepted treatment for nervous and mental disease throughout France. Jean Martin Charcot and his disciples, who operated the world's most famous chinic for the research and treatment of nervous and meutal diseases at the Salpetrière in Paris, accepted hypnosis as a legitimate, potent instrument of cure. There, Charcot and his students avidly researched the true nature of hypnosis, its relatiouship to hysteria, and the mechanisms of its healing effects. Charcot maintained a photographic laboratory and many photographs were taken of the hysterical patients and the lyypnotic experiments performed on patients and staff. A three-volume album of these photographs was published between 1876 and 1880 as $D$. Bourneville \& P. Regnard, Iconographie Photographique de la Saltpétriére. Liébeault and his associate, Hippolyte Bernheim, did similar research at Nancy. H. BERNHErM, Suggestive Therapeutics: A Treatise on the Nature and Uses of Hypnotism (trans. froin $2 d$ rev. French ed. 1886). The intense rivalry between the Nancy and the Salpetrière groups yielded a flood of scientific publications advocating their conflicting theories of hypnosis. Galdston, Hypnosis and Modern Psychiatry, 9 CrBa Symposia 845 (1947).

24. Signiund Freud, as a young physician, was the translator of the German editions of a number of the works of both Charcot and Bernheim. For a listing of the works translated by Freud, see A. Grinstein, Sigmund Freud's Writing: A CoMprehensive Bibliography 12728 (1977). At this point in his career Freud had yet to develop his theories of psychoanalysis. Freud also studied under Charcot at the Salpetriére froin October 1885 through Febrnary 1886. 1 E. Jones, The LIFE AND WORK OF Sigmund Freud 207 (1953). Hence, he was thoroughly familiar with the practice of hypnotic therapy and the conflicting theories as to its nature. When he established his own practice in Viema, he followed the then conventional and respectable use of hypnotic suggestion for the treatinent of his nervous patients. However, by 1893, he had estab- 
tional illness.

Throughout its history, hypnosis has been the subject of theatrical exhibitions and novels in Europe and America. This treatment reached a peak in the character of Svengali in du Maurier's 1894 novel Trilby, ${ }^{25}$ which reinforced the popular image of the liypnotist as a mysterious, evil person. Later, the popular mind identified the infamous monk Rasputin with malignant lyypnotic influence. ${ }^{26}$

A few researchers in the United States did, however, continue scientific and clinical investigation of hypnosis. ${ }^{27}$ World War II, with its many psychological casualties and widespread use of psychiatrists in the armed forces, produced a resurgence of interest im hypnosis for the treatment of the so-called war neuroses. ${ }^{28}$ The war years also saw the imtroduction of sodium anytal, which was imjected as a "truth serum." Indeed, "narcoanalysis," requiring less physician skill and experience and less patient cooperation than hypnosis, became the method of choice and convemience. ${ }^{29}$

Since World War II, legitimate hypnotism has been the preserve of a minority of psychiatrists who have used it to treat mental and emotional conditions. Although it has not approached the popularity of other methods of psychotherapy, it has avoided condemnation as fakery, as so often occurred in the past. Particularly in the last thirty years, academic psychologists and clinicians have accepted hypnosis as a . proper subject of research. In the mid-1950's, the British and American Medical Associations formally approved its medical use. ${ }^{30}$ A 1972 bibhography on hypnosis contains well over 1,000 references to scientific

lished, with Joseph Breuer, the foundations of a new theory of causation and treatment of nervous and emotional illness and soon abandoned his use of hypnosis. J. BREUER \& S. FREUD, STUDIEN UBER HYSTERIE (1909).

25. The novel first appeared in serial form in HARPER's MAGAzINE from January to August 1894. It was enormously popular and its publication was quickly followed by stage versions and ultimately inotion pictures.

26. There is no evidence that Rasputin practiced hypnosis, but his influence over the Czarina was popularly believed to be hypnotic. This was reinforced by the 1932 movie "Rasputin and the Empress" starring Ethel, Lionel, and John Barrymore.

27. Notably M. Erickson, M. Orne, E. Hilgard, H. Spiegel, T. Sarbin, J. Schneek, M. Gill, M. Brenman, and others. For their bibliographies, see RESEARCH, supra note 10, at 587-638.

28. W. MENNINger, Psychiatry IN A Troubled World 309-12 (1948).

29. R. Grinker \& J. SPIEgel, MEN UNDER Stress $389-406$ (1945). This treatment involved inducing a trance state or partial unconsciousness by the imtravenous injection of these powerful sedatives whicl could overcome emotional blocking, fear, and inhibitions. Repressed memories would return along with a flood of cathartic emotional outpouring, and spectacular results were often achieved in the treatment of war neuroses and combat fatigue. It was generally recognized that the psychological principles of treatment with narcoanalysis were essentially the same as with hypnosis. However, the intravenous injection of drugs was far simpler, and more rehable than hypnosis, required less skill, and was free from hypnotism's disreputable aura of mysticism and magic.

30. 12 ENCYCLOPEDIA BRITANNICA 24 (1964). 
publications of hypnosis research, the great majority of the references being post-World War II. ${ }^{31}$

There is simply no doubt, after two centuries of research and particularly the postwar scientific research, that hypnosis has been clinically and experimentally verified as a phenomenon. It is quite another question, though, whether it is a phenomenon that has a helpful role to play in criminal factinding and, particularly, in the "enhancement" of the recall of a prospective witness.

\section{II}

\section{LEGAL BACKGROUND OF HYPNOTICALLY ENHANCED TESTIMONY}

\section{A. Case Law}

The case law on testimony by witnesses who have previously been hypnotized for the purpose of "enhancing" their recall can be summarized briefly. First, it is admissible. The rationale appears to be that the combination of an opportunity for cross-exammation of the witness and the admissibility of expert testimony on the contaminating effect of hypnosis on recall pernmts the trier of fact to give proper weight to the testimony. Second, audio or video recordings of the hypnotic sessions, while apparently not mandatory, are deemed highly desirable as a record of what actually took place during the sessions. ${ }^{32}$ Third, it seems settled that the defense must be given notice that a prosecution witness has been hypnotized for the purpose of memory enhancement. ${ }^{33}$

These cases must be distimguished from those where a party seeks to introduce statements made during the hypnotic trance for the purpose of establishing the truth or falseness of alleged facts. Such statements are consistently excluded. ${ }^{34}$ Moreover, no trial court, to my knowledge, has ever endorsed hypnosis of a witness before the trier of

31. RESEARCH, supra note 10 .

32. These recordings are not, of course, admissible to establish the substance of what the witness related during hypnosis. United States v. Adams, 581 F.2d 193, 198-99 (9th Cir.), cert. denied, 439 U.S. 1006 (1978).

33. See United States v. Miller, 411 F.2d 825, 832 (2d Cir. 1969). This case involved the nonnal situation where the potice use hypnosis on a potential prosecution witness. Hence, the issue of notice to the defense was squarely presented. The issue could also arise where the defense hypnotized a potential defense witness (e.g., an ahbi witness). However, this use has not been common and there appear to be no reported cases on it. Since cases hold that the defense need not give notice to the prosecution when it uses hypnosis in aid of establishing a mental state defense, a notice requirement might not be applied to the defense where it had hypnotized a potential witness. My analysis of the nature of hypnosis and its impact on recall suggests, however, that neither side should be permitted to use hypnosis to enhance recall, and thus obviates the notice problem entirely.

34. For a summary of such cases, see Annot., 92 A.L.R.3d 442, 454 (1979). 
fact. $^{35}$ Further distinction must be made from cases which discuss the use of hypnosis on a defendant for the evaluation of his mental state by an expert defense witness. ${ }^{36}$

The first reported decision concerning the use of hypnosis for enhancement of a witness' memory was the 1968 case of Harding $v$. State. ${ }^{37}$ A psychologist hypnotized the coinplainant, the victim of rape and assault with intent to murder, for the purpose of restoring her inemory of the events of the crime. She then was able to testify (in the norinal waking state), and almost entirely on this evidence ${ }^{38}$ the defendant was convicted. Full information about the hypnosis was presented at the trial and the hypnotist testified in detail as to his procedure with the witness. The adimssibility of the testimony of both the coinplainant and the psychologist was upheld by the appellate court, and the judgment was affirmed. This case apparently set the trend for subsequent rulings that pretrial hypnotism affects credibility but not admissibility of the evidence. ${ }^{39}$

It is to be noted that the psychologist in the Harding trial testified that hypnosis does not dispose the subject to suggestion. Similar

35. But see the descriptions of the Arthur Nebb trial by Teitelbaum and by Herman, supra note 16. Even in the Nebb trial, the hypnosis took place before the trial judge outside the presence of the jury.

36. See Cornell v. Superior Ct., 52 Cal. 2d 99, 338 P.2d 447 (1959) (approving use of hypnosis for such evaluation); State ex rel. Sheppard v. Koblentz, 174 Ohio St. 120, 187 N.E.2d 40 (1962) (disapproving use).

37. 5 Md. App. 230, 246 A.2d 302 (1968), cert. denied, 395 U.S. 949 (1968). Prior decisions involved atteinpts to introduce testimony of or about a defendant who had been hypnotized. The first such case was People v. Ebanks, 117 Cal. 652 (1897), where expert testimony by a hypnotist was held not admissible to show that statements had been made by the defendant while under hypnosis that pertained to his knowledge of the homicide. The 1905 decision in State v. Exum, 138 N.C. 599 , 50 S.E. 283 (1905), concerned the possibility of posthypnotic effects upon a witness, but the context differed completely from the concern of this Article. Exun's wife was called to testify on his behalf in his trial for murder. The court ruled that the allegation that the defendant had previonsly hypnotized his wife on numerous occasions was admissible as relevant to her credibility.

38. The other evidence was that sperm had been recovered from the complainant's vagina.

39. See, e.g., Kline v. Ford Motor Co., 523 F.2d 1067 (9th Cir. 1975) (consolidated torts cases where the appellate court held erroneous the trial court's exclusion of hypnotically enhanced testimony of one plaintiff); Wyller v. Fairchild Hiller Corp., 503 F.2d 506 (9th Cir. 1974) (plaintiff in suit against helicopter inanufacturer underwent hypnotic treatınent to restore his memory, which had been impaired by the crash); Connolly v. Farmer, 484 F.2d 456 (5th Cir. 1973) (first reported civil case where hypnotically enhanced testimony-by the plaintiff-was adunitted); People v. Smrekar, 68 Ill. App. 3d 379, 385 N.E.2d 848 (1979) (a murder case where, prior to hypnosis, the principal witness stated that there was only a "50-50" chance that the defendant was the person she had seen commit the inurders); State v. McQueen, 295 N.C. 96, 244 S.E.2d 414 (1978) (sustaining the admissibility of hypnotically refreshed testimony on the theory that hypnosis is no less acceptable than any other memory-enhancing procedure); State v. Broun, 8 Or. App. 598, 494 P.2d 434 (1972) (relying on Harding, the court admitted testimony by a witness whose amnesia was cured by hypnosis and sodium amytal); State v. Jorgensen, 8 Or. App. 1, 492 P.2d 312 (1971) (saine witness as in Brom). 
claims, commonly made by prosecution-oriented hypnotists, directly contradict all scientific evidence, as will be discussed below. Perhaps if the Harding trial and appellate courts had been presented a more accurate description of the nature of hypnosis and the extreme vulnerability of the subject to suggestion, they might have been less disposed to admit the evidence, and the subsequent trend of the law might have been different.

If Harding stated the general rule of admissibility, United States $v$. Narciso ${ }^{40}$ showed how far some courts will go to apply it even when the validity of the testimony is extremely suspect. Two nurses were accused of five murders and ten counts of adding poison to the food and medicine of hospital patients. The nurses allegedly injected a curare derivative ${ }^{41}$ into the tubing through which patients were receiving medication, causing them to suffer cardiopulmonary arrest. There had been fifty-one such episodes of cardiopulmonary arrest and a number of deaths.

Richard Neely, a patient who survived a respiratory arrest, was questioned by FBI agents on two occasions. Both times he stated that he had no meinory of the poisoning. He then voluntarily submitted to two sessions of hypnosis. He vaguely described two individuals he believed to have been near his bed the night of his respiratory arrest but he made no identification. At the end of the second session he was shown a group of photographs that included defendant Perez. He recognized her as one of his nurses but did not identify her as one of the two persons who had been near his bed. He did, however, incorrectly identify a person uncolmected with the case as one of the nurses who had harmed him. A month later Neely unqualifiedly identified Perez as one of the perpetrators. In a deposition taken nine months after that identification, Neely stated that he had known all along that Perez was one of the persons in his rooin just before his poisoning but that at first he had deliberately refused to identify her im order to protect her. ${ }^{42}$

The defendants moved to suppress all testimony by Neely, relying on Simmons $v$. United States. ${ }^{43}$ They claimed that the hypnotic interrogation sessions together with the photographic array created a "very substantial likelihood of irreparable misidentification," the Simmons standard for exclusion. ${ }^{44}$ At the hearing, Dr. Dennis Walsh, a psychiatrist, testified on behalf of the defense that his psychiatric examination

40. 446 F. Supp. 252 (E.D. Mich. 1977).

41. Used as a muscle relaxant by surgeons during anesthesia and by psychiatrists to minimize the convulsions of electroshock therapy, it will, in excess dosage, cause a paralysis of all muscles, imcluding those of respiration, with fatal results.

42. 446 F. Supp. at 277-78.

43. 390 U.S. 377 (1968).

44. Id. at 384. 
of Mr. Neely revealed a terminally ill patient who had been alcoholic for many years, and had a borderline personality organization as well as memory problems. He believed the witness was a suggestible person whose memory consisted of fragments of actual memory and fantasy blended together in response to his felt need to be lielpful to the FBI. ${ }^{45}$ Dr. Martim Orne ${ }^{46}$ also testified on behalf of the defense and concluded that Mr. Neely's testimony was at least im part the product of fantasy formulated in response to subtle cues of the interviewers. Dr. Herbert Spiegel ${ }^{47}$ testified to the contrary on behalf of the government, concluding that there was no danger that Mr. Neely's statements and memories were not from his own memory.

The court determined that the defense liad failed to fulfill the "heavy burden" required by Simmons, and admitted Neely's testimony. The court said that it would "exercise its powers to see that the factors raised by the pretrial events discussed herem are presented to the jury in an intelligible fashion." 48 The two nurses were convicted, but their motion for a new trial was granted on other grounds. ${ }^{49}$

On the other liand, particularly outrageous abuses associated with hypnosis may lead to exclusion of the "refreslied" testimony. The 1975 combined cases of Emmett v. Ricketts and Creamer v. Hopper, ${ }^{50}$ which involved liabeas corpus writs brought by Georgia prisoners convicted of murder, provide an example. There the United States District Court rebuked the state prosecution and the psycliologist who had hypnotized Deborah Kidd, the chief prosecution witness to the alleged homicide. ${ }^{51}$

After a largely unsuccessful investigation of the sensational murder of two Georgia pathologists in 1971, imdictments were brought agamst the two petitioners and seven other alleged coconspirators. At the separate trials of Emmett and Creamer, convictions rested almost

45. 446 F. Supp. at $280-81$.

46. Dr. Orne is the author of many scientific publications on hypnosis and is the coauthor of the article on hypnosis in 9 ENCYCLOPAEDia BRITANNICA MACropaedia 133 (15th ed. 1979).

47. Dr. Herbert Spiegel of Columbia University is a well-known authority on hypnosis. He is coauthor of the book TRANCE AND TREATMENT: CLINICAL. USES OF HYPNOSIS (1978) and of the section on hypnosis in 2 COMPREHENSIVE TEXTBOOK OF PSYchIATRY $\$ 30.4$, at 1843 (2d ed. A. Freedman, H. Kaplan, \& B. Sadock 1975) [hereinafter TexTBOoK]. Dr. Spiegel is the discoverer of a reliable, objective test of the hypnotizability of a subject. He had hypnotized Neely in Deceniber 1975.

48. 446 F. Supp. at 284.

49. Motion for new trial, United States v. Narciso, 446 F. Supp. 252 (E.D. Mich. 1977). At the second trial, the government failed to obtain conviction.

50. 397 F. Supp. 1025 (N.D. Ga. 1975). See also Emmett v. State, 232 Ga. 110, 205 S.E.2d 231 (1974), and Creamer v. State, 232 Ga. 136, 205 S.E.2d 240 (1974), which had approved of the admission of the testimony later coudemned by the federal district court.

51. The major abuse consisted in the psychologist's acting as a police agent and literally using the hypnotic sessions (for which he was paid $\$ 3,515$ by the county) to manufacture evidence against the petitioners. 
entirely on the testimony of Deborah Kidd. No physical evidence was offered to link the petitioners or the coconspirators to the crime. Kidd's testimony was given credence by four separate juries who were unaware of the numerous discrepancies in her various versions of the crime, discrepancies deliberately concealed from the defense. Moreover, when the petitioners (then defendants) attempted to obtam access to the records and tapes of the psychologist's hypnotic sessions with $\mathrm{Kidd}$, the trial court ruled them to be privileged. ${ }^{52}$

The police had mamtained Kidd, an admitted prostitute and amphetamine addict, in isolation for some time prior to the trials. For several weeks she was quartered in the apartment of a detective assigned to the case, had sexual relations with him, and claimed to be in love with him. During this time, the police supplied her with amphetamines and she contmued her heavy drug use. At the suggestion of the county police department superintendent of detectives, Kidd was taken to a psychologist, purportedly to help her "kick" her drug habit. The United States District Court found, however, that the real purpose was to employ hypnosis to improve her memory and fill in the gaps in her recollections. Although the psychologist denied that he gave her suggestions or infornation about the crimes, he did instruct her to scan the newspapers and clip relevant articles about the case. As to the psychologist's credibility, the district court cominented: "The Court has further observed his demeanor and considered his responses to questions during his many hours of testimony in this case. The Court does not credit his testimony as to the inatters here involved." 53

The Emmett and Creamer trials were a veritable nightmare of abuse by police, prosecutors, and a cooperative psychologist-hypnotist. For that reason the granting of the writs of habeas corpus in those cases does not represent a per se rejection of pretrial hypnosis of witnesses. However, those cases are important because of their holding and their illustration of the unfortunate tendency of some psychologists to cooperate in abuses of hypnosis.

Thus, it may be surprising that courts in only two reported cases have considered imposing any procedural requirements to prevent abuse of hypnotic refreshment. In the first, United States v. Miller, ${ }^{54}$ defense counsel requested hypnosis of a principal prosecution witness in the hope of impeaching his previous identification evidence. It then

52. Emmett v. Ricketts, 397 F. Supp. 1025, 1038 (N.D. Ga. 1975). Georgia, in 1959, became the first state to adopt a psychotherapist-patient privileged communication statute that was distinguished from and much stricter than the usual physician-patient privileged communication laws. See Group for the ADVANCEMENT OF Psychiatry, REPORT No. 45, CONFIDENTIALITY AND Privileged Communication in the Practice of Psychlatry 96 (1960).

53. 397 F. Supp. at 1038 n.23.

54. 411 F.2d 825 (2d Cir. 1969). 
turned out that the witness had been hypnotized before in Texas in connection with the trial of Miller's alleged coperpetrator. The Texas hypnosis had been conducted in part by an independent expert and in part by the attorney who later served as the prosecution interrogator of this same witness in the Miller trial. The prosecution had failed to inform the defense of these facts. The appellate court held that withholding the fact of prior hypnosis was reversible error. ${ }^{55}$

The second decision that recognized the need for procedural protections was the consolidated case of United States $v$. Adams and United States $v$. Pinkerton. ${ }^{56}$ The two defendants and a third person tried separately were prosecuted for conspiracy, assault with intent to rob, robbery, and murder. Postal imspectors hypnotized an alleged eyewitness during the investigation of these crimes (which arose out of a postal robbery). The court commented that no record had been made of the identity of those present during the hypnotic session nor of the questions and responses. However, the defense did not object to the adequacy of the foundation laid for the receipt of the testimony. Instead, it sought to exclude all testimony of the witness on the grounds that no testimony from witnesses who had been hypnotized can be reliable and that therefore sucli witnesses are legally incompetent to testify. The Umited States Court of Appeals for the Ninth Circuit rejected this argument, stating that previous hypnosis of a witness affects the credibihity but not the adnnssibility of the testimony.

The Ninth Circuit, however, did warn of the dangers of abuse: We are concerned, however, that investigatory use of hypnosis on persons who inay later be called upon to testify in court carries a dangerous potential for abuse. Great care nnust be exercised to insure that stateinents after hypnosis are the product of the subject's own recollections, rather than of recall tainted by suggestions received while under hypnosis. ${ }^{57}$

And in a footnote the court added:

We think that, at a minimum, complete stenographic records of interviews of hypnotized persons who later testify should be maintained. Only if the judge, jury, and the opponent know who was present, questions that were asked, and the witness' responses can the matter be dealt with effectively. An audio or video recording of the interview would be helpful. ${ }^{58}$

Although well-intended, these warnings and cautionary remarks are not sufficient, as will be discussed in Part III.

55. Id. at 830 .

56. 581 F.2d 193 (9th Cir.), cert. denied, 439 U.S. 1006 (1978).

57. Id. at 198.

58. Id. at 199. 


\section{B. The Legal Literature}

Evidence textbooks ${ }^{59}$ and law journals have largely ignored hypnosis of witnesses as a means of enhancing witness recall. If mentioned at all, it has usually been in the context of a general discussion of the admissibility of "truth seruin"-induced statements and polygraph evidence. Furthermore, the emphasis is usually on the use of such procedures on the defendant, either to obtain specific evidence (e.g., a confession or exculpatory facts) or to probe his mental state in aid of a psychiatrist's forming an expert opinion.

The earliest comprehensive American article on point, Legal Aspects of Hypnotism, ${ }^{60}$ was published in the Yale Law Journal in $1902 .{ }^{61}$ The author warned that evidence obtained from the use of hypnosis was unreliable since hypnotic subjects can consciously lie and are extreinely susceptible to "illusions and hallucmations." He advocated the use of hypnosis only "for detective purposes."62

The next major work was Després' 1947 article, Legal Aspects of Drug-Induced Statements, ${ }^{63}$ which cautioned that hypnotically induced statements are every bit as unreliable as statements made under the influence of drugs. The article is also noteworthy for Després' observation that "At about the beginning of the century, the question of using confessions by hypnosis was widely discussed in the United States, and the inedical and legal professions apparently agreed that suggestibility played too great a role in the confessions, because 'even honest questioning may act as false suggestion." "64

An extensive 1952 student note, Hypnotism, Suggestibility and the $L a w,{ }^{65}$ emphasized the unreliability of hypnotically induced information: "A person in lypnotic state is prone to hallucmations which frequently originate false ideas which are afterwards believed true by the

59. MCCormick's Handbook of the LAW OF Evidence 510 (2d ed. 1972).

60. The author was George Trumball Ladd. 11 YALE L.J. 173 (1902).

61. Other early legal articles on hypnosis were published between 1891 and 1902 , but these did not mclude discussion of memory enhancement of witnesses. They were much more concerned with hypnosis as a possible cause of crime and the hypnotized state as a criminal defense.

For a listing of these articles, see 31 NeB. L. REV. $575 \mathrm{n.1}$ (1952). It is noteworthy that Bannister, Hypnotic Influence in Criminal Cases, 51 ALB. L.J. 87, 88 (1895), cautions: "When an individual is fully in the hypnotic condition he can be made to say anything, and even honest questioning may act as false suggestion. It is easy to see, moreover, what would be the possibilities of post-hypnotic suggestion in this regard."

62. Ladd, supra note 60 , at $187-88$.

63. 14 U. CHl. L. Rev. 601 (1947). He documents that the first use of a drug to induce a statement in a criminal case occurred in the Dallas County Jail, February 13, 1922. A physician injected scopolomine (the original so-called "truth serum") into two convicted criminals and "established to his satisfaction that they were not guilty of the crimes charged." Id.

64. Id. at 607.

65. 31 NEB. L. REV. 575 (1952). 
subject . . ." T66 The note continued: "[A] witness' opinion may be colored by suggestion or hypnosis so that his account of a factual situation may miss the truth by a wide inark." 67

In a 1955 article, Levy vehemently demanded legal recognition of hypnosis. ${ }^{68} \mathrm{He}$ advocated the admission of both testimony from witnesses who have been subject to hypnotism and evidence of the hypnotism for purposes of credibility. ${ }^{69}$ Because it appeared in a journal widely read by law enforcement personnel, this article was probably an important encouragement to police use.

A 1961 law review article, Hypnotism and the $\mathrm{Law}^{70}$ stated that "falsification of testimony can theoretically be obtamed by hypnosis since retroactive hallucinations can be firmly cemented in a subject's mind during hypnosis."71 Its concern was with the legal issue of posthypnotic influence and especially witl subornation of perjury (as it terned this use of hypnosis) by the defense. The article did not anticipate the widespread police use of hypnotisin on witnesses.

Two law review articles and a number of student notes, some quite naive, ${ }^{72}$ followed the unreported 1962 Ohio trial of Arthur Nebb. He was accused of the nonfatal wounding of his estranged wife and their

66. Id. at 583.

67. Id. at 593 . The note ultimately concluded that "there seems to be no serious reason why hypnotism should not be employed to aid in crime detection as the lie detector has, and it is in this capacity that liypnotisin can be of great service to the administration of justice." Id.

68. Levy, Hypnosis and Legal Immutability, 46 J. CRIM. L.C. \& P.S. 33 (1955).

69. Id. at 34.

70. 14 VAND. L. Rev. 1509 (1961). The author, William P. Swaine, was a recent law graduate at the time of publication.

71. Id. at 1515. He cited Allen, Hypnotism and Its Legal Import, 12 CANADIAN B. REv، 80, 88 (1934), as authority for this statement, but then he said: "An able and rigorous cross-examination can minimize the danger of falsified testimony by means of hypnosis." Swaine, supra note 70, at 1515 n.38.

72. Herman, supra note 16; Teitelbaum, supra note 16. Teitelbaum, an attorney-hypnotist, is the author of the "how-to" book on hypnosis referred to in note 7 supra. The Nebb trial also stimulated the publication of an extensive student note, Hypnosis in Court: A Memory Aid for the Witness, 1 GA. L. REv. 268 (1967). Although this student seems to have read widely in the psychological and legal literature on hypnosis, he is very naive to accept uncritically the pseudoscientific claims so frequently made in that hiterature. He urges that hypnosis be used on witnesses while on the witness stand in the courtroom whenever the witness needs some sort of prodding or refreshing of memory. An equally naive student comment is Hypno-Induced Statements: Safe. guards for Admissibility, 1970 L. \& DOC. ORD. 99. This student also demonstrates wide but uncritical reading in the literature on lyypnosis and a lack of comprehension of the legal hazards of hypnosis. For example, he states:

If the lyypno-examination is properly conducted, the resulting testiniony has the same attributes of credibility-basic honesty versus personal interest-as any other testiunony. Through pretrial discovery, an opponent can ascertain whether the witness' memory was refreshed through hypnosis, or even altered through post-liypnotic suggestion. The fact that a witness las been hypnotized and thereby possibly infiuenced by the post-hypnotic suggestion seems irrelevant to a determination of the truth of his testiniony. Absent any evidence of inipropriety, it might be assumed that the witness' memory was simply restored. Because hypno-induced testinıony has the same basic attributes of credibility as 
daughter and of the murder of his wife's lover. The defendant had been hypnotized twice by a psychiatrist-hypnotist employed by the state. By agreement of counsel and outside the presence of the jury, the expert hypnotized the defendant in the courtroom, probably the first time in the history of American jurisprudence that a witness was so hypnotized. ${ }^{73}$

Herman, in a 1964 article, The Use of Hypno-Induced Statements in Criminal Trials, ${ }^{74}$ described the trial in great detail, apparently regarding it as a landmark. He repeated the hypnotist's extravagant claims of the reliability and vahidity of hypnotically induced evidence, but recognized that the scientific hiterature, by and large, does not support such claims. Herman cautioned against the blanket refusal to admit hypnotically enhanced evidence and recommended a case-by-case approach. This article, like the Teitlebaum article, ${ }^{75}$ was preoccupied with hypnosis of the defendant and did not concern itself with what is now the major use of hypnosis for legal purposes: pretrial hypnosis of prosecution witnesses.

A 1977 article by Spector and Foster, Admissibility of Hypnotic Statements: Is the Law of Evidence Susceptible?, ${ }^{76}$ was the first to discuss fully and extensively the issue of the use of hypnosis to spur the recollection of witnesses. Although replete with references to the inedical and psychological literature, the authors, in my opinion, failed to properly distinguish hypnotically imduced memories froin more normally induced recollections. They cited many references from the scientific literature which demonstrate that all memory is frauglit with uncertainty, distortion, and is subject to distortion through suggestion. ${ }^{77}$ Their conclusions, however, did not follow:

[A] witness whose memory has been refreshed through hypnosis may be able to recount an observed event more fully and accurately than any other witness .... Where the processes of partial regression or hyperamnesis are the hypnotic stimulant, the testimony of the witness whose recollection has been so revived presents no more potential for maccuracy due to the disabilities of perception, memory, and articulation than that of any witness. ${ }^{78}$

any other testimony, to inform the jury of the hypnosis with no evidence of impropriety runs the risk of umecessarily arousing unfounded prejudices.

Id. at 112-13.

73. Teitlebauin, supra note 16 , at 210.

74. Herman, supra note 16.

75. Id.

76. 38 Ohio State L.J. 567 (1977).

77. An excellent review of the older literature is contained in Redmount, The Psychological Basis of Evidence Practice: Memory, 50 J. CRIM. L.C. \& P.S. 249 (1959). For more recent research, see Buckout, Eyewitness Testimony, ScI. AM., Dec. 1974, at 23; Fishman \& Loftus, Expert Psychological Testimony on Eyewitness Identification, 4 L. \& PSYCH. REv. 87 (1978).

78. Spector \& Foster, supra note 76, at 590. 
The authors did agree, however, that hypnosis greatly aggravates the suggestibility of the witness due both to the inherent nature of hypnosis and to the bond between hypnotist and witness. They admitted that subsequent cross-examination of the witness at the trial is meffective in revealing the implantation of false suggestions, and that the subject who has accepted a posthypnotic suggestion to forget aspects of the hypnotic procedure will generally remain unaware of the source of stateinents he inakes while testifying. ${ }^{79}$ Their solution, however, was very naive: the hypnotist should testify first to lay a foundation for the witness' testimony by describing fully the hypnotic procedures employed and by vouching for the accuracy of the restored memory. Supposedly, cross-examination of the hypnotist would reduce the hazards inherent in hypnotic preparation of the witness to "that which is ordinarily tolerated during pretrial witness preparation or interrogation sessions." 80

Spector and Foster then discussed another inherent problem in hypnotically induced statements-dehberate fabrication. They minimized its importance, however, with the assertion that cross-examination, fear of perjury prosecution, sanctity of the oath, and solemnity of the proceedings are as effective in preventing the fabrications of previously hypnotized witnesses as of ordinary witnesses. ${ }^{81}$ The problem, however, is that the fabrications which occur in hypnosis, in my clinical experience, are honest in the sense that the subject is not aware that he is fabricating. Therefore, it can hardly be expected that the usual inducements to honesty in ordinary witnesses are apt to be effective for the pretrial hypnotized witness. ${ }^{82}$

The third problem of hypnotically induced evidence that Spector and Foster recognized is the undue weight that a jury might accord to such evidence. They agreed that this effect would be pronounced with in-court hypnosis, but they saw no problem with pretrial hypnosis if a proper foundation is laid by the hypnotist's testimony. ${ }^{83}$ No inention was made of a fundamental and unresolvable problem with hypnotic enhanceinent of memory, that is, its impact on the atti-

\footnotetext{
79. Id. at 593.

80. Id. at 594 .

81. They also assert that proper instruction of the jury regarding the nature and function of hypnosis eliminates the unotive for disseınbling while in a trance state. $I d$.

82. A witness inay actually beheve quite honestly that he was not hypnotized when he in fact was. Sirhan Sirhan persists in his conviction that I never hypnotized him.

83. Spector \& Foster, supra note 76, at 596. They say, however, that "An exception ınay be ınade when the witness suffers a lapse of meinory on the witness stand. [Hypnotic] [i]nduction should be permitted, out of the presence of the jury, to revive his remembrance through induc-
} tion." Id. 
tude and demeanor of the witness, which will be discussed further in Part III.

Dillhoff's 1977 article on The Admissibility of Hypnotically Influenced Testimony ${ }^{84}$ is of special interest because it was written from the perspective of a Navy judge advocate and presented a number of military cases involving the use of hypnosis. Generally, the military courts have excluded all hypnotic evidence imcluding identifications achieved through the use of hypnotic enhancement of meinory. ${ }^{85}$ Dillhoff was unusually aware of the limitations and evidentiary dangers inherent in the use of hypnotisin, and he provided excellent descriptions throughout his article of these serious problems. Dillhoff believed, however, that these problems could be countered by expert testimony of the dangers involved in the use of hypnosis on witnesses. ${ }^{86}$ Ultimately, Dilloff concluded, like most writers before him, that, despite the unrehability and the possible invalidity of hypnotism for the enhancement of recall and elicitation of truth, "such testimony should [not] be totally excluded." 87 Hence, he termed "both impractical and unrealistic" the position I take that the entire recollection of the witness is now unreliable due to the taimt of hypnosis, rendering the witness imcompetent to testify. ${ }^{88}$

One final work that should be recognized is Dr. Orne's affidavit filed in the appeal of People v. Quaglino ${ }^{89}$ to the United States Supreme

84. 4 OHIO N.U.L. Rev. 1 (1977).

85. "[T]he conclusions based upon, and the statements of the person interviewed made during, a drug-induced or hypnosis-induced interview are inadmissible $m$ evidence in a trial by courtmartial." Manual For Courts-Martial $§ 142$ (e) (rev. ed. 1969).

86. Dillhoff, supra note 84 , at 9 . One inight conclude that the acquittal of the defendant in the case I describe in the text accompanying notes 137-4l infra substantiates Dillhoff's belief. I think not, however, as the only witness who served as an expert to vouch for the validity of the witness' testimony and for the general reliability of the hypnotic method was the police officerhypnotist, and I doubt that the jury regarded him as impartial and uninvolved. A basic problem of this kind of expert testimony is that the experts who perform the liypnosis for prosecutorial purposes, in many instanccs, seem only too willing and able to make strongly definitive statements as to the validity, reliability, and efficacy of the use of liypnosis for enhancing recall. In effect, they vouch for the truthfulness of their hypnotic subjects. The expert, sucl as myself, wlo attacks the credibility of the evidence, has no way of knowing whetler the liypnotically influenced testimony is true or false. In all lionesty, he can only testify that the hypnosis has contaminated the evidence in sucl a manner that it is impossible for him or anyone else, including the trier of fact, to make such a determination. Hence, a strong, positive opinion of the state's expert is pitted against the somewhat implausible, but I believe accurate, clain by the defense expert that lie does not know the truth and that neitler lie nor the trier of fact can ever find out.

87. Id. at 22.

88. Id. at 21 .

89. Crim. No. 29766 (Cal. 2d Dist. Ct. App.), cert. denied, 439 U.S. 875 (1978). The facts of the unpublished Quaglino case can be obtained from an unpublished manuscript, T. Worthington, Hypnotically Induced or Enhanced Testimony 18 (on file with the California Law Review). 
Court. ${ }^{90}$ Dr. Orne is a professor of psychiatry at the University of Pennsylvania and a foremost clinical and research expert on hypnosis, ${ }^{91}$ with a longstanding interest in its legal aspects. The affidavit contains a thorough, scholarly analysis of the problems associated with the use of hypnosis for inemory enhancement. However, Dr. Orne believes that the subject may later be called as a witness if the safeguards surrounding the use of hypnosis have been sufficiently strict. ${ }^{92}$

In suni, this review of the law and hterature of hypnotically enhanced witness recall offers only mixed support for my view that courts should never admit such testimony. While some courts and legal scholars have recogmized the risks of abuse and injustice that arise from the use of hypnosis to enhance recall, even they have thus far relied on procedural safeguards to minimize the risk.

III

\section{EVidentiary Problems With HypNotically MANIPULATED RECALL}

Hypnosis may have some value as an investigatory mstrument when used to enhance memory. ${ }^{93}$ However, the law should recognize that the use of hypnosis for such a purpose renders the potential witness incompetent, ${ }^{94}$ literally destroying the probative value of any evidence that the witness might otherwise have been able to produce. The following set of questions-which might be asked im court of an expert in the field of hypnosis-will illuminate the insurmountable evidentiary problems created by hypnotically refreshed testimony.

90. Leave to file granted, 439 U.S. 875 (1978). I am indebted to Dr. Orne for a copy of his affidavit.

91. See note 46 supra.

92. Certain of the concepts expressed in this Article are derived in part from personal comnunications froin Dr. Orne and from his affidavit.

93. For example, in the Chowchilla kidnapping of 26 children who had been riding in a school bus, the bus driver was able to recall under hypnosis a license plate number. This proved instrumental in the appreliension of the kidnappers. Monrose, supra note 1, at 54.

In my opinion, lowever, the value of hypnosis for investigative purposes has been greatly overstated by exaggerated claims in irresponsible books and articles. As Freud discovered long ago, whatever can be done by lyypnosis can also be done witlout hypnosis; it merely takes longer and requires greater skill and patience. My own experience convinces me that safe and effective enhancement of recall, with less liazard of suggestion and contamination of future testimony, can be accomplished without gimmieks such as liypnosis and "truth serum."

94. A liypothetical case could of course be imagined where law enforcement agents have a witness froin whoin they would like further present information about the crime for investigative purposes as well as testimony for trial use. Adoption of this rule forces them to a decision. Arguably, the public interest in effective administration of justice is disserved whichever course the police clioose. But at least two responses are possible: (1) the burden will be small since this liypothetical situation will occur fairly rarely; and (2) inore fundanentally, the law has other aims than the appreliension of criminals, and the right to be free of a conviction aided by the "transgressions of the constable" is one of its strongest. 


\section{Can a hypnotized person be free from heightened suggestibility?}

The answer is no. Hypnosis is, almost by definition, a state of increased suggestibility. The operator's suggestions control each step of the hypnotism process: ${ }^{95}$

Hypnosis can be described as an altered state of intense and sensitive interpersonal relatedness between hypnotist and patient, characterized by the patient's nonrational submission and relative abandonment of executive control to a more or less regressive, dissociated state. . . . The patient's dissociated attention is constantly sensitive to and responsive to cues from the hypnotist. ${ }^{96}$

2. Can a hypnotist, through the exercise of skill and attention, avoid implanting suggestions in the mind of the hypnotized subject?

No, such suggestions cannot be avoided. The suggestive instructions and cues provided to the subject need not be, and often are not, verbal. The attitude, demeanor, and expectations of the hypnotist, his tone of voice, and his body language may all communicate suggestive messages to the subject. Especially powerful as an agent of suggestion is the context and purpose of the hypnotic session. Most hypnotic subjects aim to please.

In order to understand the range of reports about hypnosis and the peculiar diversity of findings, it is necessary to take into account the deeply liypnotized individual's remarkable responsivity not only to explicit suggestions but also to very minute cues, often outside the observer's awareness. . . .

The cues as to what is expected may be unwittingly communicated before or during the hypnotic procedure, either by the hypnotist or by someone else, for example, a previous S[ubject], a story, a niovie, a stage show, etc. Furtler, the nature of these cues may be quite obscure, both to the hypnotist, to the S[ubject], and even to the tramed observer. ${ }^{97}$

3. After awakening, can the hypnotic subject consistently recognize which of his thoughts, feelings, and memories were his own and which were implanted by the hypnotic experience?

No. It is very difficult for human beings to recognize that some of their own thoughts might have been implanted and might not be the product of their own volition. It is only with the severely mentally disturbed, as in schizophrenia and in obsessive-compulsive neuroscs, that one's thoughts and resultant behavior are experienced as ahen. Nor-

95. E. Hilgard, The Experience of Hypnosis 9 (1968). See also Orne, On the Simulating Subject as a Quasi-Control Group in Hypnosis Research: What, Why and How, in Research, supra note 10 , at 399,400 .

96. Spiegel, Hypnosis: An Adjunct to Therapy, in TEXTBOok, supra note 47, at 1844.

97. Orne, supra note 95 , at 402. 
mally, mental processes are rationalized and experienced as the product of free will, even when it should be obvious that they are not. I have often demonstrated this to students by hypnotizing a volunteer. I tell him, once in the trance state, that some time after awakening, I will take a handkerchief out of my pocket and clean my glasses, at which time he is to walk over to the nearest window and open it. Next, I instruct the subject to have no memory of having received the instruction. The subject is then awakened. After five or ten minutes I inconspicuously take out my handkerchief to wipe my glasses. Invariably, the subject will start to show signs of restlessness and start looking at the windows. Some will act as if the room has becoine excessively warm. Soon the subject will get up, go to the window, and open it. When I ask immediately why he opened the window, the subject will reply, "I felt warm and I wanted to let soine air in," or "It's awful stuffy in here," or some similar response. Significantly, the response will show no recognition that the impulse to open the wimdow is implanted; rather, subjects feel it to be their own idea and they come up with a inore or less rational reason to justify their belief and action.

This experiment explains why the witness who has undergone pretrial hypnosis can rarely, if ever, recognize that a suggestion implanted intentionally or unintentionally by the hypnotist is not the product of his own mind. Moreover, this misperception will withstand the most vigorous cross-examination. ${ }^{98}$

\section{Is it rare for a subject to believe that he was not hypnotized when in fact he was?}

No. On the contrary, very often hypnotic subjects refuse to believe they actually went into a trance. Some claim they were wide awake during the whole experience, others that nothing unusual happened, still others that they were only pretending to be hypnotized. Sirhan Sirhan, whom I hypnotized im an effort to restore his memory of the assassmation of which he was accused, persisted in his conviction that he had never succumbed to the hypnosis. ${ }^{99}$ Actually, he repeatedly went into very deep trances during which he was very susceptible to posthypnotic suggestions. After awakening, he would consistently act out the posthypnotic suggestions, but would explain each action by a pseudological rationale. When the audiotapes of the hypnotic sessions were played back to him, he persisted in his denial that he had been hypnotized, claiming that we must have faked the recordings with

98. See Allen, supra note 71 , at 8 or 19.

99. A number of thoroughly reliable observers witnessed these trances. 
a professional actor simulating his voice. ${ }^{100}$ Finally, it is especially common for liglitly liypnotized subjects to deny that the hypnosis has "worked," for they think they remember everything that occurred during the session.

\section{Can previously hypnotized persons restrict their memory to actual} facts, free from fantasies and confabulation?

No. This question is of course central to the decision to admit hypnotically enhanced testimony. Out of a desire to comply with the hypnotist's suggestions, the subject will commonly fill in missing details by fantasy or confabulation. Often these details are portions of other real inemories, but ones unrelated to the situation that the hypnosis seeks to probe. Thus, the hypnotically recalled memory is apt to be a mosaic of (1) appropriate actual events, (2) entirely irrelevant actual events, (3) pure fantasy, and (4) fantasized details supphed to make a logical whole. The classical experiment was performed by Stalnaker and Riddle in 1932 in which students were asked to memorize various works of prose and poetry. A year later the students were tested in both the waking and the hypnotic state for their recall. In the hypnotic state, the students tended to recall more of the words of the origmal, but they consistently made inore errors of recall than they did when in the waking state, sometimes confabulating whole verses of a poem. Significantly, the students did not recognize that they were making errors of recall. ${ }^{101}$ Commenting on this experiment, Hilgard stated: "Confidence of the [hypnotic] subject in the accuracy of recovered memories does not guarantee their accuracy." 102

\section{After the hypnotic subject is awakened, do the distorting effects of the} hypnosis disappear?

This too is a critical issue for the admissibility of testimony where there has been pretrial recall enhancement. For courtroom testimony to be admissible, the witness must have emerged from the trance with his powers of recall intact and presumably enhanced, and must be able to relate from the witness stand his wholly conscious recollections as he now perceives them. ${ }^{103}$ The evidence, however, is that the effect of suggestions made during hypnosis endures. Although the more theatrical

100. Sirhan mamtained this conviction on the witness stand despite vigorous interrogation and the harm that his demal did to his defense.

101. Stahiaker \& Riddle, The Effect of Hypnosis on Long Delayed Recall, 6 J. GEN. PsYch. 429 (1932).

102. E. Hilgard, supra note 95, at 166. See also EnCyClopaedia Britannica MACROPAEDIA, supra note 16.

103. See People v. Blair, 89 Cal. App. 3d 563, 152 Cal. Rptr. 646 (2d Dist. 1979). In that case the witness emerged from the hypnotic trance with a complete amnesia for what she had recalled during the hypnotic state. 
types of posthypnotic suggestion may last only hours or days, less obvious suggestions may last years or even a lifetime. A highly pertiment example is the so-called "posthypnotic source amnesia." This occurs when soinething learned under hypnosis is carried into the wakened state but the fact that the memory or thought was learned under hypnosis is forgotten. ${ }^{104} \mathrm{~A}$ sizable proportion of hypnotic subjects spontaneously do so, and the mcidence of source anmesia can be increased by suggestions from the hypnotist. ${ }^{105}$ A subject who has lost the memory of the source of his learned information will assume that the memory is spontaneous to his own experience. Such a belief can be unshakeable, last a lifetime, and be immune to all cross-exammation. It is especially prone to "freeze" if it is compatible with the subject's prior prejudices, beliefs, or desires. This type of distorted memory is very apt to appear genume and spontaneous, and will be unlikely to disappear.

One can only conclude that hypnosis can induce subtle but highly significant distortions of memory that will persist indefinitely, distorting all subsequent related recall of the subject. My own experience has convinced me that even commumications and other cues to the subject made in the normal, waking state, both before and shortly after the hypnotic session, may be similarly influenced by the hypnotic experience. Thus the police may tell a witness something just before hypnosis and then hypnotize him. When he awakes, his "source amnesia" may lead him to believe that the police statement was a product of his own niemory. Sometimes communications made to the patient after hypnosis may be retroactively integrated into the hypnotic recall. The subject may recall a fact with no awareness that it was not the product of his own mind. Or he may recall being told the fact but insist that he had prior knowledge of it. This often happens when subjects are shown photographs or line-ups for identification just before or just after hypnotic sessions. In my experience, time, rather than weakening the effects of the liypnotic distortion, tends if anything to fix it into a permanent pattern. Therefore, the pretrial hypnosis of a witness appreciably influences all of his subsequent testimony in ways that are outside the consciousness of the witness and difficult, if not impossible, to detect.

\section{Can an experienced hypnotist or other expert detect the simulation of hypnosis?}

This question is relevant, for some persons do pretend to be hyp-

104. Although everyone has some degree of this source amnesia for information learned in childhood or many years ago, persons in the normal state of consciousness do not ordinarily maintain an amnesia for the source of their information soon after it is acquired.

105. Cooper, Hypnotic Amnesia, in RESEARCH, supra note 10, at 217, 223. 
notized when they are not. One would suppose that a skilled hypnotist could detect such faked hypnotism. However, rigorous scientific experiments have repeatedly demonstrated that even the best experts cannot consistently distimguish between actual and pretended hypnosis. ${ }^{106}$ This illustrates one of the most pressing problems of our understanding of hypnosis-no reliable and truly objective criteria of the state of hypnosis have yet been discovered.

\section{During or after hypnosis; can the hypnotist or the subject himself sort out fact from fantasy in the recall?}

Again the answer is no. No one, regardless of experience, can verify the accuracy of the hypnotically enhanced memory. Those who attempt to do so usually rely on such factors as detail, coherence, compatibility with facts gamed from other sources, and the like. True, if the recall is incoherent, illogical, and incompatible with the known facts, one can evaluate it as fantasy. However, even if it has all the earmarks of accuracy, it may still be fantasy. The subject under hypnotic influence is often eager to please by complying with the demand, explicit or tacit, that he produce a correct memory. Thus, unwittingly, the subject may comply by producing a memory out of fantasy and formulatimg it $\mathrm{m}$ as reakstic terms as he is capable. ${ }^{107}$

\section{Is the specificity and richness of the recalled memories an assurance} that the hypnotic or posthypnotic subject is recalling fact?

In ordimary life experience we tend to judge the validity and accuracy of memories by the amount of detail recalled. If I am very vague as to what I had for lunch ten days ago, we doubt my memory. But if I recall every item of the lunch and its environment in all particulars, we tend to have faith in the accuracy of my recall. Subjects under hypnosis often recall events with amazing detail and verisimilitude. Ageregression experiments have demonstrated that a person can be hypnotized and instructed to return to and beheve he is living $\mathrm{m}$ a former period of time such as his childhood. ${ }^{108} \mathrm{He}$ will be able to describe im most minute detail events and surroundimgs of that period. Whenever I have performed this experiment my behef in the reality of the acted out recall is unshakeable. But the experiment of age progression readily proves that detailed recall can be totally confabulated. A subject is hypnotized, instructed to progress in age, say, ten years im the future,

106. One must not make the error of assuming that, therefore, all hypnosis is not simulated.

107. See generally E. HILGARD, supra note 95, at 164-75.

108. Often, he will change his tone of voice and his mannerisins to suit that age and will misidentify persons about him as those appropriate to that time of his life. See Orne, The Mechanisms of Hypnotic Age Regression: An Experimental Study, $46 \mathrm{~J}$. ABnoRmal \& Soc. PsYch. 213 (1951). 
and then asked to describe his surroundings. He will relate what he imagines he sees in the greatest detail, producing in the observer the saine sense of confidence in his accuracy as does the age-regressed subject. This proves that what is principally involved in both cases is the remarkable ability of the human mind to confabulate. ${ }^{109}$

10. Does the independent corroboration of some of the hypnotically enhanced memories assure that all or most of the witness' memories are reliable?

No. In usmg hypnosis for the therapeutic recall of traunatic psychological events such as in the treatinent of combat neuroses, the therapist is unconcerned with factual accuracy. Rather, he is after the cathartic recall of the emotions surrounding the traumatic event since he assumes these to be the cause of the neurotic symptoins. In this process, ehcitation of all the einbellishments and distortions of the neurotic process is desirable. Hence, even hypnotists experienced in the therapeutic use of hypnosis may be extreinely naive in their appraisal of the reahity value of hypnotic recall. Particularly, they are apt to assume that because soine aspects of the subject's recall are verified by completely independent inforination, this imphes that the remainder of the recalled memory is also likely to be authentic. A footnote to United States v. Narciso states:

It is of interest to note that Dr. Orne, one of defendants' experts, rehes on the vahidity of his testing of suggestibility on corroboration by outside facts; thus, if a subject under hypnosis states a fact that is later found to be true by independent investigation, the probability that the stateinent was not "suggested" is increased. In that respect, at least, the inethods of the psychiatrist-liypnotist and the trier of fact are identical. ${ }^{110}$

If this is a correct statement of Dr. Orne's view, I must strongly disagree. ${ }^{111}$

The hypnotist often unconsciously cues the subject into statimg certain things. Then, when they prove correct, the hypnotist believes the memories to have been independently recalled by the subject and thus "mdependently" corroborated. In fact, the subject may have been inerely responding to the cues of the hypnotist who knew all along from other sources what the actual facts were. This is particularly

109. Rubenstein \& Newnan, The Living Out of "Future" Experiences Under Hypnosis, 119 SCIENCE 472 (1954).

110. 466 F. Supp. at 282 n.11.

111. Dr. Ome and I usually agree on most of the legal issues concerned with hypnosis, although he takes a somewhat more benign view of its use for purely investigative purposes. Orne, supra notes $46 \& 89$. 
likely to happen when the hypnotist has a prior familiarity with the police record or other facts of the criminal event.

\section{Is it possible or practical to make an adequate record of the hypnotic experience?}

Obviously, it is better to have an audiotape, or preferably a videotape, recording of the pretrial hypnotic sessions with the witness than no record at all. ${ }^{112}$ A mere transcript of the hypnotic sessions can be particularly inisleading since the hypnotist often communicates cues and suggestions through tone of voice and body language. In unsophisticated readers the transcript may thus produce a false sense of confidence that no such cues or suggestions were transmitted.

However, a complete record of the hypnotic experience is never possible for, as described above under Question Six, influcnces excrted both before and after the hypnotic session become integrated into the hypnotic experience and significantly distort the validity of recall. The only adequate record of the hypnotic experience would be a videotape of everything that transpired before, during, and after the sessions. Yet that, in itself, would be a powerful distorting factor for the knowledge that one is being recorded can alter one's attitudes and beliavior. Therefore, the confidence expressed by some courts ${ }^{113}$ in the protection offered by stenographic, audio, or video recordings of the hypnotic session is not justified.

12. Does a witness' posthypnotic demeanor, attitude of self-confidence, and appearance of integrity and honesty remain unaffected by pretrial hypnosis?

A reinarkable feature of liypnosis is its apparent ability to resolve doubts and uncertainties. Most persons, when aware of the deficiencies of their recall of events, will communicate their awareness by hesitancy, expressions of doubt, and body language indicating lack of selfconfidence. The jury relies on these indicators of lack of certainty of recall, and their importance im the determination of the weight of the evidence may be equal to or greater than the bare substance of the testimony. Witlout adding anything substantive to tle witness' memory of events, hypnosis may significantly add to his confidence im his recall. Thus, a witness who quite honestly reveals that he is unsure of the identification of a defendant from a pliotograph or a line-up, may, after hypnosis, becoine quite certain and confident that lie has picked

112. Having counsel for both sides present during the hypnotic sessions is also clearly preferable to the common practice of private, unrecorded sessions.

113. United States.v. Adams, 581 F.2d 193, 199 n.12 (9th Cir.), cert. denied, 439 U.S. 1006 (1978). 
the right man. Yet no additional memory has been recalled that would justify the mcreased confidence. Reviewing the transcripts of hypnotic sessions, I have repeatedly observed how often the hypnotist gives a strong, direct suggestion to the subject to remember, to be sure of his ineinory, to concentrate on the details, to look inwardly as if looking at a photograph. As the policeman-hypnotist in People v. Davis ${ }^{14}$ instructed the witness: "What you'll find at the end of [the hypnotic session], you'll have practically a photographic recall of everything I ask you and everything you answer . ..."15 The nature of hypnosis is such that the subject's critical judgment is suspended and he responds to the demand for exact, photographic recall even when his actual recall is vague and doubtful. It is this suspension of critical judgment which allows the hypnotist to induce illusions and hallucmations into the inind of the subject. ${ }^{116}$

\section{Can an experienced hypnotist or other expert have a reliable and} valid opinion that the recall of a particular witness whose memory has been enhanced by hypnotism is reliable and valid?

The admissibility of testimony of witnesses whose memory has been liypnotically enhanced has been justified by also admitting testiinony of the hypnotist and other psychiatric and psychological experts knowledgeable of hypnosis to impeach or support the testimony of the witness. The expert either attacks or vouches for the validity of the testimony insofar as it is related to the hypnotic experience. The jury, however, can experience this only as testimony by the experts as to the truth or falsity of the testimony-hardly a proper function of the expert witness.

It would be wrong to claim that hypnotically enhanced memories are always false or distorted. I contend, rather, that there exist no ineans to determine with certainty whether or not such falsity or distortion has been introduced by hypnotism. Thus, in my view an expert can testify only as to the probabilities of the effect of the hypnosis. This is especially true of the defense expert who may read the transcript of the hypnotic sessions, histen to the audiotapes or see the video recording, but still have absolutely no way of knowing whether the hypnotically recalled inemory is true or false. But it is true as well of the hypnotist who performed the memory enhancement and who also qualifies as an expert witness. Yet one often finds testimony by such persons in unequivocal terms that no undue suggestions have been given to the subject and that his recall was entirely spontaneous and

114. No. 52660 (Super. Ct. Placer County, California, July 30, 1979).

115. Id.

116. See generally E. HILGARD, supra note 95, at 120-49. 
undistorted. Usually the hypnotist also expresses his conviction in the truth of the recall. ${ }^{17}$

An especially serious problein in this context is that courts accept as qualifications for expertise in hypnosis the usual criteria of training and experience. I have found that, with very few exceptions, such socalled experts may be highly skilled in the therapeutic and diagnostic use of hypnosis, yet be totally unaware of its shortcomings in the context of the legal situation. Usually, they are familiar with the literature of hypnotherapy ${ }^{118}$ but often lack knowledge of the extensive experimental work of Hilgard, Orne, and the many other researchers who have made important scientific contributions to this field. Law enforcement-oriented author-hypnotists, police staff psycliologist, and policeman-hypnotists especially tend to be ignorant of the extensive body of scientific knowledge that has accumulated through research on hypnosis. Many policeman-hypnotists have taken only short courses in hypnotic technique but have read avidly and uncritically articles and books on its use in criminal investigation, and have become highly skilled in inducing the hypnotic state and interrogating subjects. They have no difficulty in qualifying as experts. Yet, their lack of scientific background and of familiarity with the research literature causes them to assert palpably false or misleading positions concerning hypnosis. In the cases in which I participated, the hypnotists who had professional training in psychology or medicine were similarly deficient in real knowledge about liypnosis even though they were skilled in its use. ${ }^{119}$ The very nature of the hypnotic experience makes it peculiarly difficult for either the subject, the hypnotist, or the observer to remain objective and emotionally detached. Here, more than in any other field of expertise, the claim of being an impartial expert is likely to be fallacious. ${ }^{120}$

14. Are the uncertainties of ordinary eyewitness testimony and those of hypnotically enhanced recall sufficiently similar that the legal rules of procedures designed for coping with the one are sufficient for the other?

Recent research has conclusively demonstrated that conventional eyewitness testimony is fraught with grave problems of inaccuracy and

117. This occurred in each of the three cases in which I participated and that are discussed more fully in Part IV infra.

118. They will usually know, for example, M. ERICKSON \& E. Rossi, HypNotherapy, AN Exploratory Casebook (1979); A. Spiegel \& D. Spiegel, Trance and Treatment, CLINICAL USES OF HYPNOSIs (1978); or earker books by these and other therapists.

119. The technique of hypnotic induction is very easy to learn and requires only confidence and practice. One can be a skilled hypnotist and know nothing about the nature and theory of hypnosis.

120. See generally Diaunond, The Fallacy of the Impartial Expert, 3 ARCHIVES OF CRIM. PsYCHODYNAMICs 221 (1959). 
distortion. ${ }^{121}$ People quite commonly fail to have seen things that happened and claim to have seen things that did not happen. Particularly, the key words used by the interrogator exert a powerful imfluence on the memory of the subject, and the distortions introduced by such suggestion inay last indefinitely, with the subject unaware that his inemory has been so altered. ${ }^{122}$ Even Bernheim, nearly 100 years ago, knew that the distortions of suggestion were not limited to subjects in a state of hypnosis, and he described cases of unhypnotized witnesses succumbing to suggestion and producing imaginary evidence. ${ }^{123}$

Nevertheless, the hypnotic subject is a great deal nnore vulnerable to suggestion than is the normal person, and the hypnotic distortions persist into the posthypnotic period with much greater force. The accepted view, that the law cannot exclude the usual eyewitness testimony where there may have been some unrehable distortions, should not justify the adinission of testimony that is known to have been subject to the mevitable distortions of the hypnotic process. The present legal attitude expressed in most case law on hypnosis is analogous to a claim that we should not even attempt to elimmate the disease of smallpox because chicken pox is so common and cannot be controlled.

I am in complete agreement with the following statement made by a public defender in the brief for a recent unpublished case:

There is no practice in which false testimony is nore "apt to harden" than hypnotic "memory enhanceinent" . . . [T] [The state of hypnosis is one of high suggestibility for the willing subject. The tendency for such a subject to confabulate, or manufacture a meinory, even with very strong subjective conviction, is inherent in the hypnotic technique. . . . The real danger is that if the subject confabulates, and the recalled memory is "eminently plausible," then it is virtually impossible for even a skilled therapist to detect such deception; and the process is irreversible. ${ }^{124}$

Pretrial hypnosis of a witness cannot be considered a harmless form of "coaching" or legitimate preparation of the witness for the courtrooin experience. In some respects it is worse than ordinary subornation of a witness for it accoinphishes the same effect, yet allows the perpetrator, the witness, and the trier of fact to remain unaware that perversion of the evidence has occurred.

121. See Woocher, Did Your Eyes Deceive You? Expert Psychological Testimony on the Unreliability of Eyewitness Identification, 29 STAN. L. REv. 969 (1977).

122. Fishman \& Loftus, supra note 77.

123. H. BERNHEIM, supra note 23 , at 177 .

124. Brief for Appellant at 29, People v. Jones, No. 67183 (Super. Ct. Alameda County, California), quoted in T. Worthington, supra note 89, at 65 . 
IV

Recent Hearings on the Admissibility of Testimony

From Witnesses Whose Memories Have

BEEN ENHANCED BY HYPNOSIS

From July 1978 to July 1979, I testified in three in limine hearings challenging the admissibility of testimony by witnesses who had been previously hypnotized. In each case I testified that the hypnotic experience had irrevocably contaminated the proposed testimony and that, were it to be introduced at trial, the trier of fact could not properly weigh its credibility. In each hearing the particular California court involved followed the trend of the case law and ruled that the testimony was admissible, but that the fact and circumstances of the liypnosis, mcluding iny expert testimony, were to be considered by the trier of fact. Details of these three cases are presented liere because they so clearly illustrate the problems facing attorneys who seek to have liypnotically enhanced testimony excluded.

In the first case, ${ }^{125}$ G.Z., age 59, was charged with sexual molestation of a nine-year-old neighbor, $M$. $M$. testified at a preliminary hearing that ten months previously the defendant had asked her if she wanted to come to his louse to help clean it. After obtaining permission from her unother, the child entered the defendant's house where, she testified, the defendant removed his pants and underpants, placed his penis agamst lier leg, and asked her to remove her pants and he on the bed, which slee did, after which lie "stuck his finger up [her] rear end." 126

The defendant strongly denied that he had molested the child, althougli he conceded that lie liad asked her to help him clean his house the day of the alleged molestation in April 1977. However, this otherwise routine child molestation case had some extraordmary features. The defendant had been convicted of a single episode of child molestation twelve years before, was placed on probation, and received private psychiatric treatment for about one year. His victim, K., had lived in the saine house now occupied by M.'s family, who liad rented it from K.'s parents in February 1977. In January 1978, K. returned to lier forner louse, staying with M.'s family. When M. reported that Mr. G.Z. was asking questions about $\mathbf{K}$., $\mathbf{K}$. revealed her molestation of twelve years before and cautioned M.'s nother not to allow Mr. G.Z. to molest $M$. as he had done to her.

The inother immediately concluded that this had already happened, probably on the child's visit to the defendant's house. She vig-

125. People v. Zehner, No. 68047 (Super. Ct. Santa Clara County, California, July 21, 1978).

126. Id. Clerk's transcript on appeal, at 8. 
orously and repeatedly interrogated the child, who denied that anything wrong had happened between her and the defendant. On August 10,1977, she brought her child to the local police department and related her behief that the child had been inolested. An officer, W., interviewed the child at length, but again she denied that the defendant had molested her. Officer W. and M.'s niother then took her to a psychologist who had previously lectured to the police department on the use of hypnosis for criminal investigative purposes. The psychologist was informed by the officer that there was a possibility the child had been molested but that she did not want to talk about it. The psychologist immediately hypnotized her. ${ }^{127}$ At this first session the child persisted in her denials. On November 17, 1977, the officer took the child again to the psychologist, and this time he remained in the room throughout the hypnotic session. There was a third session on December 7,1977 . Now, finally, the child dictated the description of the alleged molestation into a tape recorder at the police station. ${ }^{128}$

There was no audio or video recording niade of the hypnotic sessions with the child, nor any record of what questions were asked or answers given. The hypnotist had, however, niade a very brief note about the sessions in her clinical records.

The techinque of hypnosis, as described by the psychologist in her testimony at the in limine hearing, was usual-a visual stimulus and suggestions to relax and sleep. The hypnotist then suggested to the child that a bunny would take her on a trip to "wonderland," full of toys, etc. The child was next told that she was meeting "Officer Teddy Bear," and that she was to sit on his lap and tell him everything that happened between her and the defendant. At the first hypnotic session the child persisted in stating that nothing had happened. At the second one she showed considerable emotion and was visibly upset when nistructed to sit on Officer Teddy Bear's lap, but still related nothing about sexual molestation. At the third session, without hypnosis and in the mother's presence, the child for the first time said that there had been a sexual experience with the defendant. The police officer then arranged for the child to dictate the story into the recorder.

I testified that in my expert opinion the hypnotic sessions could have firmly inplanted in the child's mind the belief that the sexual experiences recounted by the nineteen-year-old friend had actually happened to her. This would be especially likely to occur in view of the suggestive effect of the repeated interrogation of the child by the

127. The psychologist neither performed any type of clinical examination of M. nor even obtained a history of her mental state.

128. There is some conflict between the statements of the child and those of the psychologist as to when the child had first admitted to the inolestation during the hypnotic sessions. 
mother, the pohice officer, and the psychologist. I emphasized that the psychologist's hypnotic instruction to beheve that she was sitting on Officer Teddy Bear's lap and to tell him what happened between her and the defendant was strongly suggestive and encouraged her to confuse sexual fact and sexual fantasy. I concluded that, as a consequence, the child's subsequent testimony was so contaminated by the hypnotic experience that no cross-examination or other means could sort out fact from fantasy. The hypnotist countered in her testimony that the child's later statements were not related to the hypnosis: "During both hypnotic sessions, she said nothing. I don't think it had anything to do with the hypnosis." 129

The court ruled:

I don't beheve that the evidence has shown any debiberate tampering with the child on the part of the people or the people's agents. My view is that the testimony of the child should be tested in the crucible of the courtroom and the truth ascertained by a trial jury and I rule that her testimony will not be excluded .... I do not find it to be the proximate result of a hypnotic trance. Now, the jury might find otherwise but I do not so find. ${ }^{130}$

The defense agreed that the criminal charge be tried on the record of the preliminary hearing together with the record of the special evidentiary hearing. The defendant was found guilty as charged, despite the total absence of any corroborative evidence. ${ }^{131}$ Appeal to the district court was unsuccessful.

The second case, People $v$. Diggs, ${ }^{132}$ more closely resembles soine of the reported cases. A twenty-six-year-old woman had been the victim of assault and attempted rape in the women's restrooin of a bar. The assailant grabbed her from behind and she struggled. When she screamed that she was pregnant and that he would kill her baby, he fled. She told the police that although she had been unable to get a good look at the man, she knew that he was black and of medium build, and she had seen his eyes briefly. She picked the defendant's photographs out of eight sets that she was shown, but was not entirely certain of her identification. ${ }^{133}$ Later at a line-up she again identified the defendant but was not certain that he was her assailant. The victim was the principal witness at trial, where her testimony revealed the same hesitancy and uncertainty about the identification of the defen-

129. Id. Reporter's transcript of proceedings held on Friday, July 21, 1978, at 102.

130. Id. at 204.

131. The defendant was also found not to be a mentally disordered sex offender.

132. People v. Diggs, No. CR 6490 (Super. Ct. Monterey County, California, Apr. 23, 1979).

133. It is significant that the photographs of other persons shown to the witness included a frontal and a side view, while those of the defendant were two frontal views. 
dant that she felt during the police investigation. There was a liung jury and a mistrial was declared.

On the recommendation of the District Attorney, a local psychiatrist liypnotized the victim. Before interviewing her, he reviewed copies of the police reports and of ler testimony at the previous trial. ${ }^{134}$ At the first of three interviews the psychiatrist took a history and performed a routine psychiatric examination. At the second and third interviews (the next day and a week later) he hypnotized ler. Tape recordings and transcripts of these two lyypnotic sessions were made, beginning only at the inornent of liypnotic induction and ending at the inoinent of awakening. No recording or transcript was inade of the mitial interview.

The lyypnotic sessions were devoted entirely to efforts by the hypnotist to regress the subject back to the original incident and to sharpen lier inental image of her assailant. He stated in his report to the District Attorney that "I lave reviewed [the tapes] and feel that I offered no suggestions which would have altered [her] recall of the situation."135 It was iny opinion, however, that the tapes and transcripts of the hypnotic sessions were replete with suggestions by the hypnotist which inarkedly altered the subject's recall. For exainple, the hypnotist frequently would first introduce some idea in his question and then receive back the saine idea in her response. Thus, although the subject had originally stated that sle liad only caught a glimpse of her assailant's eyes, general build, and black skin color, and had made no inention of a mirror, in the sessions she quickly responded to the hypnotist's suggestion that there was a mirror on the restrooin wall enabling her to see lier assailant. Slie then described, while hypnotized, inore details of the assailant's clothing and appearance as though she were viewing thein in the mirror. Toward the end of the last session, the hypnotist gave her a final suggestion: " $Q$. Susan, as you run through this, do you feel like I have suggested anything to you, or tried to change the inemory that you're running through, in any way? A. No. I see everything." 136 The subject was also encouraged to recall all that she related in the hypnotic sessions. She was now very certain that she could identify the defendant as her assailant.

At a hearing to determine the admissibility of her testimony, the psychiatrist-hypnotist testified that he had not suggested anything to

134. The psychiatrist stated in his report: "Although these materials were totally reviewed, the emphasis was to attempt to determine the areas where Mrs. A would benefit froin enhancement of her menory, and as a result of this the pictures of the defendant were purposely not viewed." Id. Report of Dr. Wilcox of Mar. 14, 1979.

135. Id.

136. Id. Transcript of tape no. 2 of hypnosis session, at 8 . 
the witness and that she was in such a light state of hypnosis that he could not have influenced her recall of the assault or her identification of lier assailant. I testified to the contrary. The court ruled to admit both her testimony and expert testimony such as the hypnotist's and mine. Bargaming between the prosecution and the defense at the urging of the defendant resulted in a plea of guilty to a lesser included offense. The defendant still professed his innocence but feared that another trial might result in a long prison sentence.

The third case concerned the hypnotism of a key witness to a homicide and armed robbery. ${ }^{137}$ It was alleged that the two defendants entered a bar in a rural community early in the evening to "case" it, returned later with their faces, except for their eyes, covered witl handkerchiefs, robbed the patrons, and killed the bartender. The prosecution of one of the defendants depended heavily upon the ability of a woman, Connie D., to identify him as botl one of the "casers" and one of the robbers. As part of the criminal investigation, Connie D. was liypnotized by the local police lieutenant. ${ }^{138}$ A complete transcript of the hypnotic session was made available to ine.

The policeinan-lyypnotist testified at the evidentiary hearing that he had not made any suggestions to the subject. Yet, consider this flagrant example:

Q. Now Connie I'm going to count to three, and touch you lightly on the left arm and when I do, these two people who were wearing masks, you'll be looking at them. When I touch you you'll be able to see them perfectly. You'll be standing right where you can get the best possible look at thein. One, two, three. That's fine. How many of thein are there?
A. $T w o .{ }^{139}$

During and after the hypnotic session the witness was still not certain of her identification of the robber, nor did sle recognize a photograph of the defendant. Nearly a year later the local newspaper pubhished an account of the crime witl a photograpll of the suspect. As soon as she saw it, the witness called the police and told them that sle

137. People v. Davis, No. 52660 (Super. Ct. Placer County, California, July 30, 1979).

138. Before inducing hypnosis the hypnotist-policeman repeatedly emphasized to the subject that human memory is like a photograpl: "Now they've pretty well determmed that everything that you ever see or hear or touch or taste or smell is all recorded. It's recorded just the way it went in and it doesn't change. It doesn't fade or anything like that." Id. Auburn Police Department transcript of hypnosis of Connie D., at 2.

Later, the hypnotist said (still before inducing the trance):

People are also kinda concerned that they won't remember what went on during the hypnosis and it may even effect [sic] their memory of the incident that they're trying to remember. What you'll find at the end of it, you'll have practically a photographic recall Id. at 9 . of everything I ask you and everything you answer....

139. Id. at 17 (emphasis added). 
was now absolutely certain that the defendant was one of the two robbers and one of the two men who had "cased" the bar.

At the evidentiary hearing, I testified that, despite the long interval between the hypnosis and the identification of the defendant, the hypnosis still might have contaminated the witness' memory and probably affected her subjective certainty of the correctness of her recall. The court admitted both her testimony and my expert testimony ${ }^{140}$ on the possible effects of hypnosis on her memory and on the identification. The defendant was acquitted, an outcome defense counsel attributes chiefly to the expert testimony. ${ }^{141}$

\section{CONCLUSION}

Many courts currently admit testimony from previously hypnotized witnesses without an adequate understanding of the nature of hypnosis and its dangers to truly independent recall. Perhaps influenced by often naive legal scholarship and biased expert testimony, these courts apparently believe that cross-examination and expert witness attacks on the credibility of such testimony will reveal any shortcomings in the lyypnosis and get to the truth. This hope is misplaced. Even if the hypnotist takes consummate care, the subject may still incorporate into his recollections some fantasies or cues from the hypnotist's manner, or lie inay be rendered more susceptible to suggestions made before or after the hypnosis. A witness cannot identify his true memories after hypnosis. Nor can any expert separate them out. Worse, previously hypnotized witnesses often develop a certitude about their memories that ordinary witnesses seldom exhibit. Further harın is caused by "expert" witnesses (often self-styled and police-oriented)

140. Due to the defendant's indigency, the county bore the expense of iny appearance. To avoid my return for another court appearance, the trial judge permitted ine to testify out of sequence. I thus was placed in the rare situation where iny testimony attacked the credibihity of a witness yet to testify.

141. One might conclude that the acquittal of the defendant substantiates Dillhofr's conclusion that "[t]he primary antedote [sic] for possible deception of the trier of fact is expert testimony describing the dangers to the judge or jury so that they may properly cvaluate the witness's testimony." Dillhoff, supra note 84, at 9. I think not, however. I suspeet that the controlling factor was that the police officer-hypnotist was the only expert to vouch for the validity of the witness' testimony and for the general reliability of the hypnotic method. I doubt that the jury regarded him as impartial and uninvolved. A basic problem of this kind of expert testimony is that the experts who perform the hypnosis for prosecutorial purposes often seem only too willing to make categorical statements as to the validity, reliability, and efficacy of the use of hypnosis for enhancing recall. In effect, they vouch for the truthfulness of their hypnotic subjects. An expert like me who attacks the credibility of the evidence can in all honesty only testify that the hypnosis has contaminated the evidence in such a manner that it is impossible for him, or anyone else, including the trier of fact, to determine the veracity of the hypnotically influenced testimony. Hence, a strong, positive opimion of the state's expert is pitted against the somewhat implausible, but I believe correct, claim by the defense expert that he doesn't know the truth and that neither he nor the trier of fact can ever find out. 
who, testifying in the state's behalf, inake extravagant, scientifically unjustified claims about the reliability of hypnotically enhanced testimony. The plain fact is that such testimony is not and calmot be reliable. The only sensible approach is to exclude testimony from previously hypnotized witnesses as a matter of law, on the ground that the witness has been rendered incompetent to testify. 